MORAES, LAS; CALORI, AH; FACTOR, TL; PATRICIO, FRA; GHINI, R; ABREU, MF; PURQUERIO, LFV. 2016. Baby leaf lettuce production in trays with reused and solarized substrate. Horticultura Brasileira 34: 463-469. DOI - http://dx.doi.org/10.1590/S0102-053620160403

\title{
Baby leaf lettuce production in trays with reused and solarized substrate
}

\section{Lívia AS Moraes ${ }^{1}$; Alex H Calori ${ }^{1}$; Thiago L Factor²; Flávia RA Patrícioº ${ }^{3}$ Raquel Ghini ${ }^{4}$ Monica F} Abreu$^{5}$; Luis FV Purquerio ${ }^{1}$

${ }^{1}$ Instituto Agronômico, Centro de Horticultura (IAC), Campinas-SP, Brasil; livia_sumam@yahoo.com.br; ahcalori@gmail.com; felipe@ iac.sp.gov.br; ${ }^{2}$ Polo Regional de Desenvolvimento Tecnológico dos Agronegócios do Nordeste Paulista (APTA), Mococa-SP, Brasil; factor@apta.sp.gov.br; ${ }^{3}$ Instituto Biológico de Campinas (IB), Campinas-SP, Brasil; flavia@biologico.sp.gov.br; ${ }^{4}$ Embrapa Meio Ambiente, Jaguariúna-SP, Brasil; raquel.ghini@embrapa.br; ${ }^{5}$ Instituto Agronômico, Centro de Solos e Recursos Ambientais (IAC), Campinas-SP, Brasil; monica@iac.sp.gov.br

\begin{abstract}
Concerning the baby leaf production in trays, substrate can be reused for a certain number of times depending on its chemical and physical characteristics, but populations of pathogens such as Pythium aphanidermatum and Rhizoctonia solani that can cause damping off of lettuce, can build up during the reuse of this substrate. Solar treatment in a solar collector can be an alternative for the disinfestation of these substrates. Thus, the objective of this research was to study the reuse of coconut fiber substrate and its solar treatment in solar collector on baby leaf lettuce production. The experimental design was randomized blocks, in a factorial scheme 4 (first-use substrate, reused once, reused twice and reused three times) x 2 (with and without solar treatment), with four replications. The substrate reused 3 times provided the highest yield, $7.4 \mathrm{~kg} / \mathrm{m}^{2}, 14.8 \mathrm{~cm}$ plant height, 7.8 leaves, length and width of the largest leaf 13.9 and $4.8 \mathrm{~cm}$, respectively; 3.4 and $0.21 \mathrm{~g} / \mathrm{plant}$ fresh and dry mass, respectively; $\mathrm{pH}$ 6.8, 0.34 and $0.35 \mathrm{dS} / \mathrm{m}$ electrical conductivity, 25.1 and $30.2 \mathrm{mg} / \mathrm{L} \mathrm{NH}_{4}^{+}$and 16.8 and $14.6 \mathrm{mg} / \mathrm{L} \mathrm{NO}_{3}^{-}$, dry density 169 and $177 \mathrm{~kg} / \mathrm{m}^{3}$ and water holding capacity 53 and $57 \%$ for substrates with and without solar treatment, respectively. There was an increase in the population of $P$. aphanidermatum, but the solar treatment was effective to eliminate this pathogen, and $R$. solani was not detected in the substrates. This study showed that the reuse of a coconut fiber substrate for one to three times could enhance the yield of lettuce baby leaf and promote the chemical and physical characteristics of the substrate.
\end{abstract}

Keywords: Lactuca sativa, coconut fiber, solar treatment device, horticulture, sustainability.

\section{RESUMO}

Produção de alface para baby leaf em bandejas com reuso e solarização de substrato

No sistema produtivo de baby leaf em bandejas, o substrato pode ser reutilizado até determinado número de vezes permitido por suas características químicas e físicas. No entanto, populações de patógenos como Pythium aphanidermatum e Rhizoctonia solani, que causam tombamento em alface, podem aumentar durante a reutilização desse substrato. $\mathrm{O}$ tratamento do substrato reutilizado em coletores solares pode ser uma opção para a sua desinfestação. Portanto, o objetivo da presente pesquisa foi verificar o efeito do reuso e solarização, em coletor solar, do substrato à base de fibra de coco na produção de alface com a finalidade baby leaf. O delineamento utilizado foi de blocos casualizados em esquema fatorial 4 (substrato sem reuso e reutilizados por uma, duas e três vezes) x 2 (com e sem solarização), em quatro repetições. No substrato de terceiro reuso, que possibilitou a maior produtividade $\left(7,4 \mathrm{~kg} / \mathrm{m}^{2}\right)$, foi verificada altura da planta de $14,8 \mathrm{~cm} ; 7,8$ folhas; comprimento e largura da maior folha de 13,9 e 4,8 cm, respectivamente; massas fresca e seca de 3,4 e 0,21 g/planta, respectivamente; $\mathrm{pH}$ de 6,8 ; condutividade elétrica de 0,34 e $0,35 \mathrm{dS} / \mathrm{m}$; teor de nitrogênio de 25,1 e 30,2

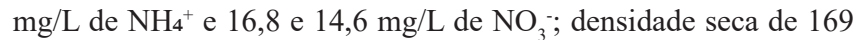
e $177 \mathrm{~kg} / \mathrm{m}^{3}$; capacidade de retenção de água de 53 e 57\% para os substratos com e sem solarização, respectivamente. Houve acréscimo na população de $P$. aphanidermatum, mas o tratamento no coletor solar eliminou o patógeno, e $R$. solani não foi detectado no substrato. Para a produção de alface baby leaf, concluiu-se que foi possível reaproveitar o substrato de fibra de coco por até três vezes e que as qualidades químicas e físicas do substrato melhoraram até o terceiro reuso, possibilitando ganho produtivo.

Palavras-chave: Lactuca sativa, fibra de coco, solarizador, sustentabilidade.

(Recebido para publicação em 9 de setembro de 2015; aceito em 11 de abril de 2016)

(Received on September 9, 2015; accepted on April 11, 2016)

$\mathrm{I}^{\mathrm{n}}$ $\mathrm{n}$ the last years, consumers have enhanced their interest in the consumption of vegetables, mainly because of improving their eating habits, as well as weight reduction and prevention of diseases. In Brazil, consumption of vegetables and fruits is still small compared to some countries in Europe and North America. The average consumption in these countries is more than 400 grams per inhabitant a day (FAO, 2009), whereas in Brazil 
the consumption is 73.9 grams per inhabitant a day, according to the Family Budget Survey (IBGE, 2009). Thus, the introduction of differentiated products on the market can stimulate people to consume more vegetables. Among these products, baby leaf is a new option in the market and it is in evidence. In baby leaf cultivation, the harvest is anticipated in relation to the period of time leafy vegetables are traditionally harvested. Thus, the leaves are still young, not fully expanded, soft, tasty and they can present different colors and shapes (Purquerio \& Melo, 2011; Calori et al., 2015). The final product has the advantage of being bought properly sanitized and ready to be consumed. Baby leaf can be grown in soil, inside or outside a protected environment, in trays used for seedling production and in hydroponic systems (Calori et al., 2014, 2015). The production of baby leaf in trays is easy to be installed and carried out. The costs are reduced when this system is compared to other production systems. However, the development of mechanical harvesting is still necessary for mass production.

Substrate and roots are kept in the trays after harvest in the production system in trays, and they become residues of the process. Thus, reuse must contribute to reduce the production cost, besides reducing the environmental impact, since a smaller amount of residue will be discarded into the environment after cultivation. Studies have highlighted interesting technical and economical results with the reuse of different substrates, without reducing yield and quality of several vegetables, such as tomato, melon and sweet pepper (Cardoso, 2009; Giuffrida et al., 2008; Urrestarazu et al., 2008; Marin et al., 2015).

Chemical and physical characteristics should be evaluated in studies involving substrate reuse, especially those aiming quality for cultivation. Also, pathogens cannot occur on the reused substrate, since they can compromise production. In Italy, Giuffrida et al. (2008) studied the reuse of perlite in tomato cultivation and did not observe any difference in yield, but observed an increase in populations of pathogens in the reused substrate, recommending monitoring.

Among the techniques available for the disinfestations of substrates, solar treatment is a powerful tool, besides being an easy to apply and a low cost method. In a Solar Collector, the substrate can be treated within a shorter period of time in relation to the conventional solar treatment (Ghini, 2004). Pathogens that can cause damping-off in the lettuce crop, such as Pythium aphanidermatum and Rhizoctonia solani, are eliminated in this equipment, that can achieve temperatures higher than $60^{\circ} \mathrm{C}$ in sunny days (Ghini, 2004).

The present research aimed to verify the effect of coconut fiber substrate reuse, solar treated or not in a solar collector, for lettuce baby leaf production, as well as to verify the chemical and physical quality of the reused substrate.

\section{MATERIAL AND METHODS}

The experiment was carried out in trays, in a seedling nursery, at Centro de Horticultura (Vegetable Crops Center) of Instituto Agronômico (Agronomic Institute), in Campinas, São Paulo State, Brazil (22 $54^{\prime} 20^{\prime \prime} \mathrm{S}, 47^{\circ} 05^{\prime} 34^{\prime \prime} \mathrm{W}, 674 \mathrm{~m}$ elevation). The protected environment structure was arch type, $3.0 \mathrm{~m}$ height (ceiling height), $13 \mathrm{~m}$ length and $7.0 \mathrm{~m}$ width, made of galvanized iron, covered with high density polyethylene (HDPE) film, $150 \mu \mathrm{m}$ thickness and closed laterally with $30 \%$ shading screen.

Inside the protected environment, temperature $\left({ }^{\circ} \mathrm{C}\right)$ and relative humidity (\%) were recorded with a datalogger (Campbell, model CR1000). From September $15^{\text {th }}$ to October $30^{\text {th }}, 2012$, the maximum, average and minimum temperatures were $30.4^{\circ} \mathrm{C}, 22.8^{\circ} \mathrm{C}$ and $17.3^{\circ} \mathrm{C}$, respectively, and the maximum, average and minimum relative humidity records were 83.1, 59.6 and $32.4 \%$, respectively.

The treatments corresponded to four reuse levels of substrate (firstuse substrate, reused once, reused twice and reused three times). The experimental design was randomized blocks, in a factorial scheme $4 \times 2$, with four replications. The substrate used in the first-use treatment (new substrate) was the coconut fiber n.11 (Golden Mix, Amafibra), with an average level of fertilization, according to the manufacturer, $68.2 ; 21.6 ; 32.2$; $234.0 ; 8.0 ; 4.9 ; 0.3 ; 8.0 \times 10^{-2} ; 0.28$; $7.0 \times 10^{-2} ; 3.2 \times 10^{-1} \mathrm{mg} / \mathrm{L} \mathrm{N}^{-N_{3}}, \mathrm{~N}_{3} \mathrm{NH}_{4}$, $\mathrm{P}, \mathrm{K}, \mathrm{Ca}, \mathrm{Mg}, \mathrm{B}, \mathrm{Cu}, \mathrm{Fe}, \mathrm{Mn}$, Mo and $\mathrm{Zn}$, respectively, electric conductivity (EC) $1.1 \mathrm{mS} / \mathrm{cm}$ and $\mathrm{pH} 6.2$.

The substrates reused once, twice and three times were residues obtained from a previous experiment (Moraes, 2013). Preparation of the substrates obtained from reuse was carried out after the lettuce baby leaf of the previous cultivation, harvested with scissors. The plant root systems remained in the trays with the used substrate, forming clods. The clods were taken from the trays and air-dried, in a protected environment, over plastic canvas. Then, these clods were spread forming a layer of approximately $5.0 \mathrm{~cm}$ thickness to dry. After drying, the clods were manually broken and sieved $(5.0 \mathrm{~mm}$ mesh). Solar treatment was carried out in a Solar Collector, according to the methodology of Ghini (2004), at Empresa Brasileira de Pesquisa Agropecuária (Brazilian Agricultural Research Corporation), in Jaguariúna, São Paulo State, Brazil. The substrate was kept in the equipment for 24 hours, on a sunny day in order to allow the temperature inside the equipment to exceed $60^{\circ} \mathrm{C}$.

For sowing, the authors used polypropylene trays with $162\left(31 \mathrm{~cm}^{3}\right)$ cells (Purquerio et al., 2016). After, the trays were filled with the coconut fiber, three pelleted lettuce seeds, cv. Elisa (Sakata), were sown onto each cell and subsequently covered, with expanded vermiculite. After sowing, the trays remained stacked for 24 hours and afterwards they were taken to the seedling nursery, where they were randomly distributed. Each tray formed a plot.

Irrigation was carried out by microaspersion, and the substrate humidity was kept close to field capacity. The fertilizations were carried out with a watering can, through applying 500 $\mathrm{mL}$ of nutrient solution per tray. For the nutrient solution composition, the 
authors used ammonium nitrate (32\% $\mathrm{N})$ and formulated mixed fertilizer 6-12$36\left(\mathrm{~N}-\mathrm{P}_{2} \mathrm{O}_{5}-\mathrm{K}_{2} \mathrm{O}\right)$, with the addition of $1.8 \%$ magnesium, $8 \%$ sulfur and micronutrients $(0.07 \% \mathrm{Fe} ; 0.025 \% \mathrm{~B}$; $0.01 \% \mathrm{Cu} ; 0.04 \% \mathrm{Mn}, 0.004 \% \mathrm{Mo}$; $0.025 \% \mathrm{Zn}$ ) at a concentration of 1.50 $\mathrm{g} / \mathrm{L}$. During the experiment, a total of 2.9; 0.6; $1.8 ; 0.9$ and $0.4 \mathrm{~g} \mathrm{~N}, \mathrm{P}, \mathrm{K}, \mathrm{Mg}$ and $\mathrm{S}$ and $1.0 ; 0.5 ; 4.0 ; 2.0 ; 2.0$ and 1.0 mg B, Cu, Fe, Mn, Mo and Zn were applied to each tray.

Harvest was carried out 39 days after sowing (DAS), before the largest leaf reached $15 \mathrm{~cm}$ length, measured from the beginning of the petiole to the end of the leaf blade, the maximum size for a leaf to be classified as baby leaf (Purquerio et al., 2016; Calori et al., 2014).

During the harvest, the authors evaluated plant height; number of leaves per plant; length of the largest leaf, measured from the beginning of the petiole to the end of the leaf blade; width of the largest leaf; aerial part, fresh and dry mass, obtained after being dried in a forced air circulation oven at $60^{\circ} \mathrm{C}$ until constant mass, and yield.

In order to characterize the substrates, pH chemical analyses, EC and $\mathrm{N}$ content in the form of ammonium ions $\left(\mathrm{NH}_{4}{ }^{+}\right)$ and nitrate $\left(\mathrm{NO}_{3}^{-}\right)$were carried out according to the methodology proposed by Abreu et al. (2007) and physical analyses of wet density and water holding capacity were carried out using the official method of Ministério da Agricultura Pecuária e Abastecimento (MAPA) (Ministry of Agriculture, Livestock and Food Supply) under Normative Instruction 17 (MAPA, 2007) altered by the Normative Instruction 31 , October $23^{\text {rd }}, 2008$. For the detection of Rhizoctonia solani, radish (Raphanus sativus) was used as an indicator plant, according to the methodology adapted from Singleton et al. (1992) and Patrício et al. (2007). For the detection of Pythium aphanidermatum, cucumber (Cucumis sativum) was used as an indicator plant, according to the methodology adapted from Lourd et al. (1986, 1987). The analyzed samples of the first use substrate, solarized or non-solarized, were not used for disease evaluation.

The data were subjected to analysis of variance. When the F-test was significant the means were compared by the Tukey test at $5 \%$ of probability.

\section{RESULTS AND DISCUSSION}

The authors noticed the effect of substrate reuse, but no effect of solar treatment influencing plant height, number of leaves per plant (NF), length and width of the largest leaf, fresh and dry mass and yield (Table 1).

The highest plant height (14.8 $\mathrm{cm}), \mathrm{NF}(7.8)$ and length $(13.9 \mathrm{~cm})$ and width $(4.8 \mathrm{~cm})$ of the largest leaf were observed in the substrate with the highest number of reuses (3 times). In this substrate, the chemical and physical characteristics changed throughout its successive reuses, favoring the development of lettuce plants and resulting in the values observed for the third reuse. The values observed in this treatment were higher than the values verified in the other treatments (Table 1), as well as the values of $12.0 \mathrm{~cm}, 5.7$ leaves, 14.9 and $4.7 \mathrm{~cm}$ observed by Purquerio et al. (2016), also for the cv. Elisa using a new (not-reused) substrate, at 30 DAS.

Regardless of the number of substrate reuses, the length of the largest leaf did not reach the maximum limit of $15.0 \mathrm{~cm}$ suggested by Purquerio et al. (2016). However, for the third substrate reuse, the largest leaf length exceeded the maximum limit of the range 6.0 to $12.0 \mathrm{~cm}$ suggested by Clarkson et al. (2005), due to the substrate chemical and physical characteristics, which enhanced plant growth. For the third substrate reuse, harvest should be anticipated in order that the plants could be harvested within the length bounds suggested.

The highest values of fresh mass (3.4

Table 1. Plant height (ALT), number of leaves per plant (NF), length (COMP) and width (LARG) of the biggest leaf, fresh (MF) and dry (MS) weight and yield (PROD) of lettuce in function of the number of reuses and solar treatment \{altura da planta (ALT), número de folhas por planta (NF), comprimento (COMP) e largura da maior folha (LARG), massa fresca (MF) e seca (MS) por planta e produtividade (PROD) de plantas de alface em função do número de reusos do substrato e solarização\}. Campinas, IAC, 2012.

\begin{tabular}{|c|c|c|c|c|c|c|c|}
\hline \multirow{2}{*}{ Reuse (times) } & \multirow{2}{*}{ ALT (cm) } & \multirow{2}{*}{ NF } & \multirow{2}{*}{$\begin{array}{c}\text { COMP } \\
\text { (cm) }\end{array}$} & \multirow{2}{*}{$\begin{array}{c}\text { LARG } \\
\text { (cm) }\end{array}$} & MF & MS & \multirow{2}{*}{$\begin{array}{l}\text { PROD } \\
\left(\mathrm{kg} / \mathrm{m}^{2}\right)\end{array}$} \\
\hline & & & & & \multicolumn{2}{|c|}{ (g/plant) } & \\
\hline 0 & $10.1 \mathrm{~d}^{1}$ & $6.0 \mathrm{c}$ & $9.5 \mathrm{~d}$ & $3.9 \mathrm{~d}$ & $2.2 \mathrm{~d}$ & $0.14 \mathrm{~d}$ & $4.6 \mathrm{~d}$ \\
\hline 1 & $11.6 \mathrm{c}$ & $6.3 \mathrm{c}$ & $10.9 \mathrm{c}$ & $4.4 \mathrm{c}$ & $2.6 \mathrm{c}$ & $0.17 \mathrm{c}$ & $5.6 \mathrm{c}$ \\
\hline 2 & $12.4 \mathrm{~b}$ & $7.2 \mathrm{~b}$ & $11.5 \mathrm{~b}$ & $4.6 \mathrm{~b}$ & $2.8 \mathrm{~b}$ & $0.19 \mathrm{~b}$ & $5.9 \mathrm{~b}$ \\
\hline 3 & $14.8 \mathrm{a}$ & $7.8 \mathrm{a}$ & $13.9 \mathrm{a}$ & $4.8 \mathrm{a}$ & $3.4 \mathrm{a}$ & $0.21 \mathrm{a}$ & $7.4 \mathrm{a}$ \\
\hline LSD & 0.43 & 0.35 & 0.49 & 0.18 & 0.10 & 0.01 & 2.00 \\
\hline CV (\%) & 2.54 & 3.63 & 11.50 & 2.95 & 2.48 & 3.88 & 2.44 \\
\hline Solarized & $12.3 \mathrm{a}$ & $6.8 \mathrm{a}$ & $11.5 \mathrm{a}$ & $4.5 \mathrm{a}$ & $2.7 \mathrm{a}$ & $0.18 \mathrm{a}$ & $5.9 \mathrm{a}$ \\
\hline Not solarized & $12.2 \mathrm{a}$ & $6.8 \mathrm{a}$ & $11.5 \mathrm{a}$ & $4.4 \mathrm{a}$ & $2.7 \mathrm{a}$ & $0.18 \mathrm{a}$ & $5.9 \mathrm{a}$ \\
\hline LSD & 0.23 & 0.18 & 0.26 & 0.15 & 0.05 & 0.05 & 5.7 \\
\hline $\mathrm{CV}(\%)$ & 2.54 & 3.63 & 11.20 & 2.95 & 2.48 & 3.88 & 2.44 \\
\hline
\end{tabular}

${ }^{1}$ Means followed by the same lowercase letter in column are not different by Tukey $5 \%$ (médias seguidas das mesmas letras minúsculas nas colunas não diferem estatisticamente entre si, Tukey $5 \%$ ). 
Table 2. Means for $\mathrm{pH}$, electrical conductivity (CE), $\mathrm{NH}_{4}^{+}$and $\mathrm{NO}_{3}{ }^{-}$content, dry density (DS) and water holding capacity (CRA) determined in coconut fiber substrate in function of the number of reuses and solar treatment $\{\mathrm{pH}$, condutividade elétrica do substrato (CE), teor de $\mathrm{NH}_{4}^{+}$e $\mathrm{NO}_{3}^{-}$, densidade seca (DS) e capacidade de retenção de água (CRA) determinadas em substrato fibra de coco em função do número de reusos e solarização\}. Campinas, IAC, 2012.

\begin{tabular}{|c|c|c|c|c|c|c|c|c|c|c|c|}
\hline \multirow{3}{*}{$\begin{array}{l}\text { Reuse } \\
\text { (times) }\end{array}$} & \multirow{3}{*}{ pH } & \multirow{2}{*}{\multicolumn{2}{|c|}{$\frac{C E}{(d S / m)}$}} & \multicolumn{2}{|c|}{$\mathbf{N H}_{4}^{+}$} & \multicolumn{2}{|c|}{$\mathrm{NO}_{3}^{-}$} & \multirow{2}{*}{\multicolumn{2}{|c|}{ DS $\left(\mathrm{kg} / \mathrm{m}^{3}\right)$}} & \multirow{2}{*}{\multicolumn{2}{|c|}{ CRA (\%) }} \\
\hline & & & & \multicolumn{4}{|c|}{$(\mathrm{mg} / \mathrm{L})$} & & & & \\
\hline & & $\mathbf{S L}^{1}$ & $\mathrm{NS}^{2}$ & SL & NS & SL & NS & SL & NS & SL & NS \\
\hline 0 & $6.2 \mathrm{a}$ & $1.3 \mathrm{Aa}$ & $1.2 \mathrm{Ab}^{3}$ & $5.3 \mathrm{Ca}$ & $5.8 \mathrm{Ca}$ & $2.5 \mathrm{Da}$ & $2.0 \mathrm{Da}$ & $99 \mathrm{Da}$ & $95 \mathrm{Db}$ & $49 \mathrm{Ba}$ & $51 \mathrm{Ca}$ \\
\hline 1 & $6.7 \mathrm{~b}$ & $0.3 \mathrm{Ba}$ & $0.3 \mathrm{Ca}$ & $6.7 \mathrm{Ca}$ & $7.1 \mathrm{Ca}$ & $8.5 \mathrm{Cb}$ & $10.1 \mathrm{Ca}$ & $129 \mathrm{Ca}$ & $132 \mathrm{Ca}$ & $46 \mathrm{Cb}$ & $54 \mathrm{Ba}$ \\
\hline 2 & $6.8 \mathrm{~b}$ & $0.3 \mathrm{Ba}$ & $0.4 \mathrm{BCa}$ & $12.3 \mathrm{Ba}$ & $12.6 \mathrm{Ba}$ & $11.4 \mathrm{Ba}$ & $10.6 \mathrm{Ba}$ & $151 \mathrm{Ba}$ & $152 \mathrm{Ba}$ & $52 \mathrm{Ab}$ & $53 \mathrm{BCa}$ \\
\hline 3 & $6.8 \mathrm{~b}$ & $0.3 \mathrm{Ba}$ & $0.4 \mathrm{Ba}$ & $25.1 \mathrm{Ab}$ & $30.2 \mathrm{Aa}$ & $16.8 \mathrm{Aa}$ & $14.6 \mathrm{Ab}$ & $169 \mathrm{Ab}$ & $177 \mathrm{Aa}$ & $53 \mathrm{Ab}$ & $57 \mathrm{Aa}$ \\
\hline LSD & 0.13 & 0.04 & 0.04 & 3.02 & 3.02 & 0.89 & 0.89 & 4.48 & 4.48 & 2.01 & 2.01 \\
\hline $\mathrm{CV}(\%)$ & 1.21 & 3.63 & 3.63 & 5.30 & 5.80 & 3.90 & 3.90 & 1.39 & 1.39 & 1.66 & 1.66 \\
\hline
\end{tabular}

${ }^{1}$ Solarized (solarizado); ${ }^{2}$ Not solarized (não solarizado); ${ }^{3}$ Means followed by the same uppercase letter in column and lowercase letter in line are not different by Tukey 5\% and F 5\%, respectively (médias seguidas das mesmas letras maiúsculas nas colunas e minúsculas nas linhas não diferem estatisticamente entre si pelos testes de Tukey e F, respectivamente, $5 \%$ ).

$\mathrm{g} /$ plant $)$, dry mass $(0.21 \mathrm{~g} /$ plant $)$ and yield $\left(7.4 \mathrm{~kg} / \mathrm{m}^{2}\right)$ were also observed on the substrate with the greatest number of reuses, totalizing an increase of approximately $35 \%$ and $33 \%$ for fresh and dry mass, in relation to the firstuse substrate (Table 1). As mentioned before, the chemical and physical characteristics of the substrate on the third reuse promoted the development of lettuce plants in relation to the other treatments. No standard was found in Brazilian literature in order to verify if the results obtained for fresh and dry mass were satisfactory. The results for fresh mass $2.2 \mathrm{~g} / \mathrm{plant}$ and dry mass $0.13 \mathrm{~g} /$ plant observed by Purquerio et al. (2016) for lettuce, cultivated in a first-use substrate, were very close to the observed in the present research using the same substrate and they were lower than the values verified in all the treatments with reused substrate, highlighting the advantage of reused substrates over the first-use substrate.

Information on the yield of baby leaf lettuce is still rare due to the innovative character of this product, regardless of the production system used. For baby leaf lettuce, cv. Elisa, produced in trays, Purquerio et al. (2016) obtained the yield of $5.9 \mathrm{~kg} / \mathrm{m}^{2}$. Also in trays, but using floating, Fallovo et al. (2009) observed $3.5 \mathrm{~kg} / \mathrm{m}^{2}$ for baby leaf lettuce 'Green Salad Bowl'. In NFT hydroponics, evaluating cv. Vera, Calori et al. (2014) verified the yield of $3.1 \mathrm{~kg} / \mathrm{m}^{2}$. Thus, regardless of the production system and the cultivar used, the highest yield of 7.4 $\mathrm{kg} / \mathrm{m}^{2}$, verified in the present research with substrate on the third reuse, can be considered high when compared to the yields observed in other researches. The authors also highlight that the yield of $5.9 \mathrm{~kg} / \mathrm{m}^{2}$ verified on the second reuse substrate was similar to the verified by Purquerio et al. (2016) and higher than the yield obtained by Fallovo et al. (2009) and Calori et al. (2014).

Considering the chemical characteristics of the substrates, no interaction between substrates and solar treatment was noticed for $\mathrm{pH}$. Nevertheless, the authors observed interaction between reuse and solar treatment for the variables $\mathrm{EC}, \mathrm{N}$ in the form of ammonium $\left(\mathrm{NH}_{4}^{+}\right)$and nitrate ions $\left(\mathrm{NO}_{3}^{-}\right)$.

On the third-reuse substrate, which allowed the highest yield, the authors observed a $\mathrm{pH}$ of 6.8 , which did not differ from the values observed on the second and first-reuse substrates. The lowest $\mathrm{pH}$ of 6.2 , was observed on the first-use substrate (Table 2). This $\mathrm{pH}$ coincides with what the manufacturer states. While evaluating coconut fiber substrates of different origins, Evans et al. (1996) verified values of $\mathrm{pH}$ between 5.6 and 6.9 , which coincided with the verified in this research, in all treatments. Results presenting an increase in $\mathrm{pH}$ on reused substrates, similar to the verified in this work, although with tomato and cucumber, were also found by Baevre \& Guttormsen (1984). The increase in
$\mathrm{pH}$ could be influenced by the quality of the water used for irrigation ( $\mathrm{pH}$ 7.6) with high concentrations of bicarbonates (99.4 mg/L).

For EC, in substrates with and without solar treatment, the highest values, 1.30 and $1.16 \mathrm{dS} / \mathrm{m}$, respectively, were verified in the first-use substrate, differing from the reused, which showed lower values (Table 2). This higher value of EC on the first-use substrate in comparison to the others may have been due to the initial chemical composition of the substrate. The present substrate was enriched with fertilizers and correction by the manufacturer. Observing only the reused substrates, the authors noticed that the EC tend to increase with successive reuses, in this case, without solar treatment (Table 2). With the reuse of coconut fiber substrate, Cardoso et al. (2010) verified an increase in the EC from $1.30 \mathrm{dS} / \mathrm{m}$ to $2.31 \mathrm{dS} / \mathrm{m}$ on the third reuse. These values were higher than the ones found in the present research, probably because those authors worked with sweet pepper and melon until the end of the crop cycle, applying a higher amount of fertilizers.

The EC could be a limiting factor in lettuce growing for baby leaf on reused substrate due to osmotic stress caused by high salinity (Kämpf, 2000). However, the authors verified that this high salinity did not interfere with the quality of the plants obtained and it was not a limiting factor in the substrate reuse. Species and cultivars of plants 
Table 3. Incidence of Rhizoctonia solani and Pythium aphanidermatum in coconut fiber substrate in function of the number of reuses and solar treatment (incidência de Rhizoctonia solani e Pythium aphanidermatum em substrato fibra de coco em função do número de reusos e solarização). Campinas, IAC, 2012.

\begin{tabular}{lccc}
\hline \multirow{2}{*}{ Reuse (times) } & \multicolumn{3}{c}{ Healthy plants emergence (\%) } \\
\cline { 2 - 4 } & Rhizoctonia solani & \multicolumn{1}{c}{ Pythium aphanidermatum } \\
\cline { 2 - 4 } & $93.6 \mathrm{~A}^{1}$ & Solarized & Not solarized \\
\hline 0 & $93.6 \mathrm{~A}$ & $100.0 \mathrm{Aa}$ & $100.0 \mathrm{Aa}$ \\
1 & $93.9 \mathrm{~A}$ & $100.0 \mathrm{Aa}$ & $98.0 \mathrm{Aa}$ \\
2 & $90.4 \mathrm{~A}$ & $100.0 \mathrm{Aa}$ & $95.8 \mathrm{Aa}$ \\
3 & 7.54 & $100.0 \mathrm{Aa}$ & $58.8 \mathrm{Bb}$ \\
\hline LSD & $93.7 \mathrm{~A}$ & ------- & ----- \\
\hline Solarized & $92.0 \mathrm{~A}$ & --------- & ----- \\
Not solarized & 3.97 & ------ & 5.24 \\
\hline LSD & 5.83 & 5.24 & 3.82 \\
CV $(\%)$ & 3.82 & \\
\hline
\end{tabular}

${ }^{1}$ Means followed by the same uppercase letter in column and lowercase letter in line are not different by Tukey $5 \%$ and F 5\%, respectively (médias seguidas das mesmas letras maiúsculas nas colunas e minúsculas nas linhas não diferem estatisticamente entre si pelo teste de Tukey e F, respectivamente, 5\%); Control treatment without inoculation (healthy plants emergence): Rhizoctonia solani $100 \%$ and Pythium aphanidermatum $100 \%$. Inoculated control (healthy plants emergence): Rhizoctonia solani $24 \%$ and Pythium aphanidermatum $27 \%$ \{controle não inoculado (emergência plantas sadias): Rhizoctonia solani 100\% e Pythium aphanidermatum $100 \%$. Controle inoculado (emergência plantas sadias): Rhizoctonia solani $24 \%$ e Pythium aphanidermatum $27 \%$ \}.

have different responses concerning EC. For lettuce, salinity tolerance is $1.3 \mathrm{dS} / \mathrm{m}$, and this species is considered moderately sensitive to EC (Medeiros, 2001). Fortunately the values verified in the present research, regardless of the treatment, are below the aforementioned tolerance.

Despite the EC did not vary on the reused solar treated substrates and did not vary between the non-solar treated substrates of the second and third reuses, the $\mathrm{N}$ content in the form of ions ammonium $\left(\mathrm{NH}_{4}{ }^{+}\right)$and nitrate $\left(\mathrm{NO}_{3}^{-}\right)$, residual in the substrates, increased with the number of reuses (Table 2). The highest contents, 25.1 and $30.2 \mathrm{mg} / \mathrm{L} \mathrm{NH}_{4}{ }^{+}$and 16.8 and $14.6 \mathrm{mg} / \mathrm{L} \mathrm{NO}_{3}^{-}$, with and without solar treatment, respectively, were observed on the third-reuse substrate. Between the first-use substrate and the treatment with three reuses, all receiving solar treatment, the authors noticed an increase of approximately 4.7 and 6.7 times in $\mathrm{NH}_{4}{ }^{+}$and $\mathrm{NO}_{3}^{-}$contents and, without solarization, 5.2 and 7.3 times. Thus, the authors concluded that plants grown on the substrates with higher number of reuses had higher amounts of available residual nitrogen for their growth, besides the amount provided by the fertilizations, which were similar in all treatments. The $\mathrm{N}$ content in the substrate was the chemical characteristic which caused the greatest differentiation in phytotechnical characteristics and yield discussed above (Table 1). A similar result for the increase of nitrate content in successive reuses, although with sweet pepper and melon, was observed in a research carried out by Cardoso (2009) in which the concentration of $74.3 \mathrm{mg} / \mathrm{L}$ verified on the first use increased 44\% (128.6 $\mathrm{mg} / \mathrm{L}$ ) up to the third reuse.

With respect to the substrate physics, in the treatments with or without solar treatment, the authors observed an increase in the average dry density and water holding capacity with the successive reuses (Table 2), reaching, respectively, a maximum of 169 and $177 \mathrm{~kg} / \mathrm{m}^{3}$ and $53 \%$ and $57 \%$ on the third-reuse substrate. According to Kämpf (2000), density can undergo changes according to the management practices carried out at the time of filling the trays or during irrigation; however, the authors believe that the increase in the dry density observed was due to the reduction in the particle size of the reused coconut fiber substrates, as well as due to the presence of residual root systems from the previous cultivations, also in small particles. Thus, the authors estimate that with the increase in the number of reuses and density of the substrate, a higher amount of substrate per tray will be necessary.

The increase in water holding capacity observed can be explained, according to Spomer (1979), by the cementing effect among the particles thereof. With reuse, probably the decomposition of organic substrates may have contributed to reduce the particle size. Those new and smaller particles occupied free spaces formed by the arrangement of larger particles, transforming macropores into micropores (Ansorena, 1994). The authors highlight that expanded vermiculite was used to cover the trays during the sowing of each new experiment (Moraes, 2013), and, according to Martins et al. (2009), this is a material with high water holding capacity, that can absorb up to five times its own volume of water. Thus, vermiculite may have also contributed to the increase in water holding capacity with the successive reuses. The authors also highlight that besides vermiculite, the incorporation, in each new cultivation, of the residual organic matter of lettuce root systems, which is a kind of organic matter different from the initial substrate (coconut fiber), may also have contributed for the same purpose. Similarly to the observed in this study, Cardoso et al. (2010) verified an increase in water holding capacity, through reusing the coconuthusk fiber substrate. With respect to the solar treatment, only for the first-use substrate, the authors did not notice any statistical difference, higher values being observed for the non-solar treated ones. Probably, the high temperature reached by the solar collector did not interfere in the first-use substrate as in the reused substrates.

Evaluating the incidence of $R$. solani, 
no difference among the substrates was noticed concerning reuse. An average of $92.3 \%$ of healthy plants was observed in all treatments (Table 3). For the control carried out without $R$. solani, $100 \%$ of healthy plants was obtained but for the inoculated control, at the end of the experiment, only $24 \%$ of healthy plants remained, confirming the absence of $R$. solani in the substrates of all treatments.

The presence of $P$. aphanidermatum was observed in no one of the solar treated substrates; where the authors observed $100 \%$ of healthy plants at the end of the experiment, proving the effectiveness of the solar treatment in the solar collector. However, without the solar treatment, the lowest number of healthy plants was observed in the third-reuse substrate, $58 \%$, showing the presence of the pathogen and an increase in the risk for lettuce cultivation. In the control without the pathogen, $100 \%$ healthy plants was observed and in the inoculated control only $27.0 \%$ of healthy plants remained viable. The detection of the pathogen on the third-reuse substrate may be due to the contamination by dust particles, structures, equipment or by the water used for irrigation. The authors could also conclude that a gradual infestation by the pathogen occurred with the successive cultivations on the non-solar treated substrate, more evident on the third-reuse substrate and, that solar treatment was very efficient for the disinfestation of the reused substrates.

Both $R$. solani and $P$. aphanidermatum are pathogens that can be a threat to cultivations carried out on reused substrates. Therefore the solar treatment in the soil collector not only proved to be effective to eliminate these pathogens (Ghini et al., 2003, 2004), but also can be an important practice to keep the sanitary standard in commercial crops of lettuce baby leaf. The study also highlights the importance of adopting other practices for sanitization, such as cleaning structures and containers used during the production process.

The authors concluded that the coconut substrate could be reused up to three times in the lettuce baby leaf production and that the chemical and physical qualities of the substrates improved up to the third reuse, providing a yield gain.

\section{ACKNOWLEDGEMENTS}

To Sakata Seeds and JKS Industrial companies for collaborating; to Fundação de Amparo à Pesquisa do Estado de São Paulo (FAPESP) (São Paulo Research Foundation) for Master scholarship granted (11/01407-1) and to Conselho Nacional de Desenvolvimento Científico e Tecnológico (CNPq) (National Council for Scientific and Technological Development) for financial support (477615/2011-2).

\section{REFERENCES}

ABREU, MF; ABREU, CA; SARZI, I; PADUA JUNIOR, AL. 2007. Extratores aquosos para a caracterização química de substratos para plantas. Horticultura Brasileira 25: 184-187.

ANSORENA, JM. 1994. Sustratos: propiedades y caracterización. Madrid: Mundi-Prensa 172p.

BAEVRE, OA; GUTTORMSEN, G. 1984. Reuse of peat bags for tomatoes and cucumbers. Plant and Soil 77:207-214.

CALORI, AH; FACTOR, TL; LIMA JUNIOR, S; MORAES, LAS; BARBOSA, PJR; TIVELLI, SW; PURQUERIO, LFV. 2014. Electrical conductivity of nutrient solution and plant spacing on yield of table beet and lettuce. Horticultura Brasileira 32: 426-433.

CALORI, AH; MORAES, LAS; PURQUERIO, LFV; FACTOR, TL; LIMA JÚNIOR, S; TIVELLI, SW. 2015. Electric conductivity and space between plants on baby leaf production in NFT hydroponic system inside greenhouse. Acta Horticulturae 1107: 303-310.

CARDOSO, AF. 2009. Desempenho de hibridos de melão rendilhado cultivados em substrato da fibra da casca de coco reutilizada: Jaboticabal: UNESP. 49p (Masters dissertation).

CARDOSO, AF; CHARLO, HCO; ITO, LA; CORÁ, JE; BRAZ, LT. 2010. Caracterização física do substrato reutilizado da fibra da casca de coco. Horticultura Brasileira 28: 385-392.

CLARKSON, GJJ; ROTHWELL, SD; TAYLOR, G. 2005. End of day harvest extends shelf life. HortScience 40: 1431-1435.

EVANS, MR; KONDURO, S; STAMPS, RH. 1996. Source variation in physical and chemical properties of coconut coir dust. HortScience 34: 965-967.

FALLOVO, C; ROUPHAEL, Y; REA, E; BATTISTELLI, A; COLLA, G. 2009. Nutrient solution concentration and growing season affect yield and quality of Lactuca sativa var. acephala in floating raft culture. Journal of the Science of Food and Agriculture, 89: 1682-1689.
FAO, Food and Agriculture Organization of the United Nations. 2009, May, $17^{\text {th }}$. Database. Available in http://faostat3.fao.org/faostatgateway/go/to/home/E.

GHINI, R. 2004. Coletor solar para desinfestação de substratos para produção de mudas sadias. Jaguariúna: Embrapa Meio Ambiente. 5p. (Circular técnica técnico, 4).

GHINI, R; PATRICIO, FRA; SOUZA, MD; SINIGAGLIA, C; BARROS, BC; LOPES, MEBM; TESSARIOLI NETO, J; CANTARELla, H. 2003. Efeito da solarização sobre propriedades físicas, químicas e biológicas de solos. Revista Brasileira Ciência Solo 27: 71-79.

GIUFFRIDA, F; LEONARDI, C; MARFA, O. 2008. Substrate reuse in tomato soilless cultivation. Acta Horticulturae 801: 15771582.

IBGE - Instituto Brasileiro de Geografia e Estatística. 2009. 07 de janeiro. Pesquisa de orçamentos familiares 2008-2009. Available in http://www.ibge.gov.br/home/estatistica/ populacao/condicaodevida/pof/2008_2009 analise_consumo/default.shtm

KÄMPF, AN. 2000. Produção comercial de plantas ornamentais. Guaiba: Agropecuária 254.

LOURD, M; ALVES, MLB; BOUHOT, D. 1986. Análise qualitativa e quantitativa de espécies de Pythium patogênicas dos solos no município de Manaus I. Fitopatologia Brasileira 11: 479-485.

LOURD, M; ALVES, MLB; BOUHOT, D. 1987. Análise qualitativa e quantitativa de espécies de Pythium patogênicas dos solos no município de Manaus II. Fitopatologia Brasileira 12: 215-218.

MARIN, MV; MELO, DM; GOMES, RF; DINIZ, GMM; RABELO, HO; CASTOLDI, R; GOBATO, ED; AZEVEDO, RG; BRAZ, LT; FERNANDES, C. 2015. Effects of different nutrient concentrations and reuse of substrate in tomato production. Acta Horticulturae 1107: 297-302.

MARTINS, CC; BOVI, MLA; SPIERING, AH. 2009. Umedecimento do substrato na emergência e vigor de plântulas de pupunheira. Revista Brasileira Fruticultura 31: 224-230.

MEDEIROS, JF. 2001. Salinização em áreas fertirrigadas: manejo e controle. In: FOLEGATI, MV; CASARINI, E; BLANCO, FF; BRASIL, RPC; RESENDE, RS (eds). Fertirrigação: frutas, flores e hortaliças. Guaiba: Agropecuária, p.201-240.

MINISTÉRIO DAAGRICULTURA, PECUÁRIA E ABASTECIMENTO (MAPA). 2007. Instrução Normativa SDA $N^{\circ} 17$. Diário Oficial da União, Seção 1, nº 99, 24 de maio de 2007. Métodos Analíticos Oficiais para Análise de Substratos para Plantas e Condicionadores de Solo.

MORAES, LAS. 2013. Produção de baby leaf de alface em bandejas com reaproveitamento de substrato: Campinas: IAC, Centro de Horticultura. 78p (Masters dissertation).

PATRÍCIO, FTA; KIMATI, H; TESSARIOLLI NETO, J; PETENATTI, A. 2007. Solarização 
do solo em casa-de-vegetação e campo para controle de Rhizoctonia solani AG-4. Summa Phytopatologica 33: 245-251.

PURQUERIO, LFV; CALORI, AH; MORAES, LAS; FACTOR, TL; TIVELLI, SW. 2016. Produção de baby leaf em bandejas utilizadas para produção de mudas e em hidroponia NFT. In: NASCIMENTO, WM; PEREIRA, RB (eds). Produção de mudas de hortaliças.
Brasília: Embrapa. p. 221-253.

PURQUERIO, LFV; MELO, PCT. 2011. Hortaliças pequenas e saborosas. Horticultura Brasileira 29: 1-1.

SINGLETON, LL; MIHAIL, JD; RUSH, CM. 1992. Methods for research on soilborne phytopathogenic fungi. APS Press: Wisconsin. $266 \mathrm{p}$.
SPOMER, LA. 1979. Three simple demonstrations of the physical effects of soil amendment. HortScience 14: 75-77.

URRESTARAZU, M; PILAR, CM; GABINO, AM. 2008. Effect of substrate reutilization on yield and properties of melon and tomato crops. Journal of Plant Nutrition 31: 20312043. 